ORIGINAL ARTCLE

\title{
Establishment of Immunohematological Reference Values among HIV Sero-negative Pregnant Women at St. Paul's Hospital Millennium Medical College (SPHMMC), Addis Ababa, Ethiopia
}

\author{
Addisu Gize Yeshanew ${ }^{1}$, Yeshwondm Mamuye GebreSilasie ${ }^{1}$, Hirut Tadesse Mengesha ${ }^{2}$
}

\section{OPEN ACCESS}

Citation: Addisu Gize Yeshanew, Yeshwondm Mamuye GebreSilasie, Hirut Tadesse Mengesha. Establishment of Immunohematological Reference Values among HIV Sero-negative Pregnant Women at St. Paul's Hospital Millennium Medical College (SPHMMC), Addis Ababa, Ethiopia. Ethiop J Health Sci.2017;27(6):641.

doi:http://dx.doi.org/10.4314/ejhs.v27i6.9

Received: June 3, 2017

Accepted: August 1, 2017

Published: November 1, 2017

Copyright: (C) 2017 Addisu Gize et al.

This is an open access article distributed under the terms of the Creative Commons

Attribution License, which permits unrestricted use, distribution, and reproduction in any medium, provided the original author and source are credited.

Funding:St. Paul's Hospital Millennium

Medical College.

Competing Interests: The authors

declare that this manuscript was approved by all authors in its formand that no competing interest exists.

Affiliation and Correspondence:

${ }^{1}$ Microbiolgy department, St. Paul's Hospital Millennium Medical College, Addis Ababa, Ethiopia

${ }^{2}$ Laboratory department, St. Paul's Hospital Millennium Medical College, Addis Ababa, Ethiopia

*Email:konjoaddisu@gmail.com,

addisu.gize@sphmmc.edu.et

\section{ABSTRACT}

BACKGROUND: Normal pregnancy is characterized by profound changes in almost every organ and system. Immunohematological parameters are important in clinical practice for the assessment of health and disease. Therefore, this study was aimed to establish immunohematological reference range among HIV sero-negative pregnant women.

METHODS: A cross-sectional study was conducted among HIV sero-negative pregnant women at St. Paul's Hospital Millennium Medical College (SPHMMC), Addis Ababa, Ethiopia, from 20/130/6/ 2016. Whole blood was collected and immunological and hematological parameters were measured following the standard procedure. Data were entered in to Epi Info version 3.5, checked for completeness and exported to SPSS version 20 software for analysis. The mean $\pm S D$ and 95\% Confidence Interval (95\% CI) values were calculated for different immunohematological parameters.

RESULTS: A total of 400 women with mean age $\pm S D(27.3 \pm 4.7)$ ranging from 18-40 years were enrolled. The mean $\pm S D$ reference value of white blood cells count with $95 \%$ CI was $8.3 \pm 2.3$ (8.1-8.6) $x 10^{9}$ cells/L and for $\mathrm{CD}^{+}, \mathrm{CD}^{+}$, and CD4to $\mathrm{CD8}$ ratio cells absolute count with 95\% CI were $906 \pm 404$ (867-946), 698 378 (662-736) cell/ul, and 1.5 \pm 0.9 (1.4-1.6), respectively.

The mean $\pm S D$ reference values for red blood cells count with $95 \%$ CI was 4.5 \pm 0.5(4.4-4.5) $10^{12} / \mathrm{L}$, for hemoglobin 14 $\pm 7.2(13.3-14.7)$ $\mathrm{gm} / \mathrm{dl}$, and for hematocrite was 39.5 \pm 4(39-39.9).

CONCLUSIONS: These values were lower than the one from developed countries but not lower than the one from other African studies. It suggests the need for further large study.

KEYWORDS: Immunohematological References, Pregnant Women, Reference Values 


\section{INTRODUCTION}

Reference value results are obtained by measurement of a particular type of quantity on an adequate number of persons in the selected group to represent the general population (1). These values are influenced by many factors in general and pregnancy in particular $(1,2)$. Pregnancy is a state characterized by many immunohematological changes, which may appear to be pathological in the non-pregnant state because the fetus faces a complex set of immunological demands, avoidance of harmful inflammatory immune responses that can lead to pre-term delivery (3).

Haematological and immunological reference ranges are important in clinical practice for the assessment of health and disease. However, inappropriate reference values may increase the risk of either unnecessary additional investigations or mismanagement of patients. Therefore, addressing those issues properly, it is useful for measuring disease progression, response to therapy, and in the assessment of adverse reactions to therapy (4).

Many of the hematological indices are influenced by many factors like sex, seasonal variation, lactation, pregnancy health and nutritional status (5). It is also acknowledged that for comparisons between individuals and with reference data in a clinical diagnostic situations, it is necessary to consider the normal variations (6). As one study revealed, there were significant decreases in RBCs count, hemoglobin (Hgb) and packed cell volume (PCV) of pregnant women compared to non-pregnant women. This study also showed total white blood cells count was increased significantly (7) and increased level of appetite too (8). Anemia (low hemoglobin) is a widely identified hematological abnormality (9), and it is associated with adverse pregnancy outcomes (10).

Although a single study which determines immunohematological reference values has been done among factory workers, immunohematological reference values for pregnant women in Ethiopia have never been established (11). However, few attempts were made to determine hemoglobin and hematocrit levels in some populations $(12,13)$.

The immunohematological reference values which are currently used in the country are adopted from textbooks which refer mainly to non-Ethiopian subjects. Hence, the need to establish Ethiopian immunohematological reference values for pregnant women is mandatory especially in monitoring of HIV/AIDS and anemia. In addition, this study is important because an attempt to predict and/or improve pregnancy outcomes during antenatal care are dependent on immunohaematological indices. Therefore, the present study was aimed to determine immunohematological reference values among HIV sero-negative pregnant women.

\section{MATERIALS AND METHODS}

Study Design and Setting: Institution based cross sectional study was carried out at ANC clinics at St. Paul's Hospital Millennium Medical College (SPHMMC), Addis Ababa, Ethiopia, from $01 / 03 / 2016$ - 30/03/2016. SPHMMC is a referral hospital in Addis Ababa under the Ethiopian Federal Ministry of Health (FMOH). It has 13 a departments out of which antenatal care (ANC) clinics, and laboratory departments are among the lists. The document obtained from the hospital indicate that 27, 780 individuals used ANC service and 131,256 individuals served for hematology laboratory tests per year.

Source population: All pregnant women attending ANC clinics at St. Paul's Hospital Millennium Medical College (SPHMMC), Addis Ababa, Ethiopia, was the source population.

Study population: The study population was apparently health HIV sero-negative pregnant women attending ANC clinics at St. Paul's Hospital Millennium Medical College (SPHMMC), Addis Ababa, Ethiopia, during the study period for antenatal followup.

Sample size determination: The sample size was determined based on the recommended guide line of Clinical and Laboratory Standards Institute (CLSI). 
Sampling technique: We reviewed daily recorded data from antenatal clinics. We calculated the daily average pregnant women flow who attended the antenatal clinics. Finally, study subjects were selected through systematic random sampling method.

Inclusion criteria: People were included up to $50 \mathrm{~km}$ from Addis Ababa if they lived at least for 6 months in their residence. Their age should be 18 years and above. The absence of active clinical disease conditions, being pregnant and free of HIV-1/2, syphilis and hepatitis B antibodies in their serum were the inclusion criterias.

Exclusion criteria: Any pregnant women who had febrile illness like mycobacterium tuberculosis and malaria and chronic noninfectious disease like allergy and arthritis and diabetes mellitus were excluded. Additionally, any vaccination in the past 6 months, taking steroid therapy in the past three months, any antibiotic usage four weeks prior to enrollment and using iron supplement, blood transfusion in the past 6 months were excluded from the study.

\section{Data collection instrument}

Socio-demographic and clinical data: After obtaining informed consent, structured pre-tested questionnaire was used to collect sociodemographic and clinical data. Socio-demographic data were age, marital status, educational status, occupation, monthly income, nutritional status, gestational age, smoking habit and the use of alcohol consumption. Clinical data were gathered for the presence and absence of active disease like diabetes mellitus and allergies. Uses of steroid therapy for the last three month, blood and blood product transfusion or vaccination for the past six months were also assessed. Both the clinical and socio-demographic data were taken from pregnant women by antenatal care (ANC) providers working at ANC clinics.

Blood sample collection and processing: Whole blood was collected with a vacutainer system in 10-ml tubes containing EDTA from consented pregnant women. All samples were collected between 7:00 and 12:00 a.m. to minimize circadian variation at the ANC clinics. HIV status of the study participants were determined by rapid test following the national HIV Rapid Testing Algorithm. Absence of sero status of syphilis and hepatitis B were confirmed using rapid strip immunoassay techniques at the ANC clinics, and sero-negative samples were analyzed in the laboratory on the same day of sample collection.

Hematological analysis: The CELL-DYN 1800 was used. The CELL-DYN 1800 aspirates approximately $30 \mu \mathrm{L}$ (microliters) of whole blood from an open collection tube that has been held under the Sample Aspiration Probe, and transfers the sample to the Pre-Mixing Cup. The CELLDYN 1800 is designed to automatically perform the following functions: Aspirate and dilute whole blood, Count, size and classify cells present in a whole blood specimen, Analyze raw data collected, and Output results to the display, printer and on-line computer.

This instrument is designed to classify the following formed elements of EDTAanticoagulated blood: White Blood Cell Parameters such as WBC-White Blood Cell or leukocyte count, \%GRAN-Granulocyte percent, \%LYM-Lymphocyte percent, \%MXD-Mixed cells (mononuclear, Eosinophil and Basophil cells together in percent), PLT - Platelet count, MPVMean Platelet Volume. Red Blood Cell Parameters: RBC-Red Blood Cell or erythrocyte count, Hct-Hematocrit, MCVMean Cell Volume, RDW-Red Cell Distribution Width. Hemoglobin Parameters: HGBHemoglobin concentration, $\mathrm{MCH}-$ Mean Cell Hemoglobin, MCHC-Mean Cell Hemoglobin Concentration is used for whole-blood analysis of hematological parameters. The machine automatically dilutes a whole-blood sample of $29.6 \mu 1$, lyses, counts and gives a printout result of absolute numbers of leukocytes (WBC) (expressed as number of cells $\times\left[10^{9}\right]$ per liter), erythrocytes (RBC) (number of cells $\times\left[10^{12}\right]$ per liter), platelets (number of cells $\times\left[10^{9}\right]$ per liter), lymphocytes (number of cells in percent), mixed cells for mononuclear cells, eosinophil and basophils (number of cells in percent), granulocytes (number of cells $\times\left[10^{9}\right]$ per liter), hemoglobin (in grams per deciliter) and hematocrit (in percent).

Immunological analysis: The FACS Calibur system, a modular bench top flowcytometer from

DOI: http://dx.doi.org/10.4314/ejhs.v27i6.9 
Becton Dickinson Immunocytometry Systems (BDIS) was used. It consists of a sensor module, a computer module and various software packages. Designed for applications that ranged from routine clinical to advanced research, this system analyzes cells as they pass one at a time through a focused laser beam. The FACS Calibur system can measure several parameters, including forward light scatter (FSC), side light scatter (SSC) and several fluorescence parameters plus the pulse area and width of any fluorescence parameter.

As a cell passes through the laser, the FACS Calibur electronics system, using the sort gate characteristics, quickly determines whether that cell is a cell of interest (target cell). The target cell is then captured according to the preselected sort mode. Because laser alignment and stream velocity are fixed, the time it takes for desired cells to travel from the laser intercept to the catcher tube is constant. When the decision is made to capture the target cell, the electronics waits for a fixed period of time to allow the cell to reach the catcher tube and then triggers the catcher tube to swing into the sample stream to capture the cell.

Lymphocyte subsets were analyzed using a FACS Calibur flow cytometer (Becton Dickinson Immunocytometry Systems, San Jose, Calif.) with two monoclonal antibodies (aCD4 and a CD8; Becton Dickinson Immunocytometry Systems). In brief, $100 \mu$ of whole blood was mixed and incubated at room temperature for 20 minutes with $10 \mu 1$ of CD4 and CD8 monoclonal antibodies. RBCs were lysed by adding $2 \mathrm{ml}$ of fluorescenceactivated cell sorter lysing solution (Becton Dickinson Immunocytometry Systems). After vortexing, tubes were incubated in the dark at room temperature for 10 minutes.

Data quality control: The English version of the structured questionnaire was translated in to Amharic and was pretested on pregnant women attending ANC clinics at Black Lion Hospital, Addis Ababa, Ethiopia, to check its validity. According to the pretest, some amendments or corrections were made. Manufacturer's instructions were strictly followed for each of the tests during laboratory work. Moreover, in order to ensure accuracy and precision of the test run, the instruments were calibrated daily by running known values of control before the start of the test or whenever new lots of the reagents were changed.

Data analysis procedure: Data were entered in to Epi Info version 3.5.1, checked for completeness and exported to SPSS version 20 software for analysis. Descriptive analysis was made to determine the socio-demographic and clinical characteristics of thr study participants. The mean, standard deviation and $95 \%$ CI values were calculated for immunohematological parameters.

Ethical considerations: Ethical clearance was secured from the Ethical Review Committee of SPHMMC. The purposes and the importance of the study were explained, and written consent was taken from participants. Participants, who had HIV infections, were referred to the HIV care and treatment clinic for further management after post counseling and excluded from the study.

\section{RESULTS}

A total of four hundred (400) study participants (100 for $1^{\text {st }}$ trimester, 150 for $2^{\text {nd }}$ trimester and 150 for $3^{\text {rd }}$ trimester) pregnant women were included.

Socio-demographic characteristics: The mean age \pm SD of the women was $(27.3 \pm 4.7)$ and ranged from $18-40$ years. The majority of the participants were $42 \%(\mathrm{n}=168)$ educated Grade 1 $8^{\text {th }}, 29.8 \%(\mathrm{n}=119)$ Oromo ethnic group, $51.8 \%$ $(\mathrm{n}=207)$ Orthodox religion follower, $58.5 \%$ $(n=234)$ House Wife regarding occupational status. Half of the participants had 1072-1571Birr monthly income according to Ethiopian salary in public procurement and property disposal service and $97.3 \%(n=390)$ were married. Regarding their addresses, 244(61\%) of the participants were from SPHMMC whereas 156(39\%) were referred from other health institutions. Concerning their sociodemographic characteristics, the mean age of the participant was $27.3 \pm 4.7$, and had a body mass index (BMI) of $24.3 \pm 3.8 \mathrm{~kg} / \mathrm{m}^{2}$. 
Table 1: Socio-demographic characteristics among HIV Sero-negative Pregnant Women at St. Paul's Hospital Millennium Medical College (SPHMMC), Addis Ababa, Ethiopia, from 01/03/2016 - 30/03/2016.

\begin{tabular}{|c|c|c|}
\hline Characteristics & Classifications & Number of women $(\%)$ \\
\hline Age & $\begin{array}{l}<21 \mathrm{yrs} \\
21-25 \mathrm{yrs} \\
26-30 \mathrm{yrs} \\
31-35 \mathrm{yrs} \\
>36 \mathrm{yrs}\end{array}$ & $\begin{array}{c}41(10.3) \\
115(28.8) \\
162(40.5) \\
61(15.3) \\
21(5.3)\end{array}$ \\
\hline Education & $\begin{array}{l}\text { Illiterate } \\
\text { Grade } 1-8^{\text {th }} \\
\text { Grade } 9-10^{\text {th }} \\
\text { Grade } 11-12^{\text {th }} \\
\text { Diploma } \\
\text { Degree and Above }\end{array}$ & $\begin{array}{c}52(13.0) \\
168(42.0) \\
63(15.8) \\
55(13.8) \\
34(8.5) \\
28(7.0)\end{array}$ \\
\hline Ethnicity & $\begin{array}{l}\text { Oromo } \\
\text { Amhara } \\
\text { Tigri } \\
\text { SNNP } \\
\text { Others }\end{array}$ & $\begin{array}{c}119(29.8) \\
117(29.3) \\
15(3.8) \\
147(36.8) \\
2(0.5)\end{array}$ \\
\hline Religion & $\begin{array}{l}\text { Orthodox } \\
\text { Muslim } \\
\text { Protestant } \\
\text { Catholic } \\
\text { House Wife }\end{array}$ & $\begin{array}{l}207(51.8) \\
143(35.8) \\
46(11.5) \\
4(1.0) \\
234(58.5)\end{array}$ \\
\hline Occupation & $\begin{array}{l}\text { Private workers } \\
\text { Government Employee } \\
\text { Merchant } \\
\text { Farmer } \\
\text { Others }\end{array}$ & $\begin{array}{c}90(22.5) \\
44(11.0) \\
16(4.0) \\
13(3.3) \\
3(0.8)\end{array}$ \\
\hline Monthly Income & $\begin{array}{l}<817 \text { Birr } \\
\text { 1072-1571 Birr } \\
>2058 \text { Birr }\end{array}$ & $\begin{array}{c}56(14) \\
202(50.5) \\
142(35.5)\end{array}$ \\
\hline
\end{tabular}

We established the mean \pm SD reference values with $95^{\text {th }} \mathrm{CI}$ of immunohematological values for each trimester. The mean $\pm \mathrm{SD}$ with $95^{\text {th }} \mathrm{CI}$ for
WBC (x109 cells/L) was $8.3 \pm 2.3(8.1-8.6), \mathrm{RBC}$ $\left(\mathrm{X} 10^{12}\right.$ cells/L) $4.5 \pm 0.5 \quad(4.4-4.5)$ and Platelet $\left(\mathrm{x} 10^{9}\right.$ cells $\left./ \mathrm{L}\right) 228 \pm 68(221.6-235)$. 
Table 2: Mean \pm SD (95\% CI) Immunohematological Values, among HIV Sero-negative Pregnant Women with their gestational category at St. Paul's Hospital Millennium Medical College (SPHMMC), Addis Ababa, Ethiopia, From 01/03/2016 - 30/03/2016.

\begin{tabular}{lcccl}
\hline Variables & $\begin{array}{l}1^{\text {st }} \text { Trimester } \\
(1-13 w k s), \mathrm{N}=100\end{array}$ & $\begin{array}{l}2^{\text {nd }} \text { Trimester } \\
(14-27 w k s), \mathrm{N}=150\end{array}$ & $\begin{array}{l}3^{\text {rd }} \text { Trimester }(28- \\
42 \mathrm{wks}), \mathrm{N}=150\end{array}$ & $\begin{array}{l}\text { Overall } \\
(\mathrm{N}=400)\end{array}$ \\
\hline WBC $\left(x 10^{9}\right.$ cells/L) & $7.3 \pm 2.01(6.5-8)$ & $8.3 \pm 2.3(8-8.7)$ & $8.5 \pm 2.3(8-8.8)$ & $8.3 \pm 2.3(8.1-8.6)$ \\
Neutrophil $(\%)$ & $64 \pm 10.9(60-68)$ & $69 \pm 6.9(68-70)$ & $67 \pm 8.9(65.6-68)$ & $67.9 \pm 8.4(67-68.7)$ \\
Mixed $(\%)$ & $9.4 \pm 6.4(7-12)$ & $8.5 \pm 3.7(8-9)$ & $9 \pm 6.1(8-10)$ & $8.8 \pm 5.2(8.3-9.3)$ \\
Lymphocyte $(\%)$ & $27 \pm 8.3(23.4-30)$ & $22.5 \pm 5.9(21.6-23.4)$ & $24 \pm 7.3(23-25)$ & $23.6 \pm 7(23-24.3)$ \\
Platlet(x10 cells/L) & $240 \pm 71.4(212-267)$ & $230 \pm 65.3(220-239)$ & $226 \pm 69.3(216-235)$ & $228 \pm 68(221.6-235)$ \\
$\mathrm{CD}^{+}(\mathrm{cells} / \mu \mathrm{l})$ & $802 \pm 260(700-903)$ & $885 \pm 370(830-941)$ & $940 \pm 444(878-1002)$ & $906 \pm 404(867-946)$ \\
$\mathrm{CD}^{+}(\mathrm{cells} / \mu \mathrm{l})$ & $591 \pm 252(494-689)$ & $658 \pm 319(610-706)$ & $750 \pm 430(690-810)$ & $698 \pm 378(662-736)$ \\
$\mathrm{CD} 4: \mathrm{CD} 8 \mathrm{Ratio}$ & $1.5 \pm 0.6(1.3-1.7)$ & $1.5 \pm 0.5(1.4-1.6)$ & $1.5 \pm 1.2(1.3-1.7)$ & $1.5 \pm 0.9(1.4-1.6)$ \\
$\mathrm{RBC}\left(\mathrm{X} 10^{12} \mathrm{cells} / \mathrm{L}\right)$ & $4.8 \pm 0.54(4.6-5)$ & $4.5 \pm 0.5(4.4-4.5)$ & $4.5 \pm 0.5(4.4-4.6)$ & $4.5 \pm 0.5(4.4-4.5)$ \\
$\mathrm{Hgb}(\mathrm{gm} / \mathrm{dl})$ & $14.3 \pm 1.7(13.7-15)$ & $14.3 \pm 1.1(12.6-16)$ & $13.8 \pm 1.5(12.6-14)$ & $14 \pm 7.2(13.3-14.7)$ \\
$\mathrm{Hct}(\%)$ & $41.4 \pm 4.7(40-43)$ & $39 \pm 3.9(38-40)$ & $40 \pm 4(39-40)$ & $39.5 \pm 4.0(39-39.9)$ \\
$\mathrm{MCV}(\mathrm{fl})$ & $87 \pm 4.0(85-88)$ & $88 \pm 5.8(86.7-88.4)$ & $89 \pm 5.7(88-89)$ & $88 \pm 5.7(87.4-88.5)$ \\
$\mathrm{MCH}(\mathrm{pg} / \mathrm{dl})$ & $30 \pm 1.5(29.4-30.5)$ & $30 \pm 2.2(30-30.6)$ & $30.7 \pm 2.3(30.4-31)$ & $30.5 \pm 2.2(30-30.7)$ \\
$\mathrm{MCHC}(\mathrm{g} / \mathrm{dl})$ & $34.6 \pm 1.2(34-35)$ & $34.6 \pm 1.5(34.4-34.8)$ & $34.7 \pm 1.4(34.5-35)$ & $34.6 \pm 1.4(34.5-34.8)$ \\
\hline
\end{tabular}

WBC $=$ White Blood Cell count, Mixed=mixed cell, $C D^{+}=$Cluster of Differentiation positive cells, RBC $=$Red Blood Cell, $\mathrm{Hg} b=$ Hemoglobin, Hct= Hematocrite, $M C V=$ mean corpuscular volume, $M C H=$ mean corpuscular Hemoglobin, $M C H C=$ mean corpuscular hemoglobin concentration, CI=Confidence Interval

In order to estimate the reference intervals that might change with age, the mean and $95^{\text {th }}$ confidence intervals were establish by age partition for WBC, platelets (Table 3 and 4), RBC and their indices (Tables 5 and 6). The mean (95\% CI) for MCV and MCHC nearly increase as the age groups classification increases whereas RDW appears to be decreased (Table 6).

Table 3: Distribution mean value with 95\% CI WBC, Platelet and Differential count, among HIV Seronegative Pregnant Women by age groups at St. Paul's Hospital Millennium Medical College (SPHMMC), Addis Ababa, Ethiopia, From 01/03/2016 - 30/03/2016.

\begin{tabular}{lcllllll}
\hline $\begin{array}{l}\text { Age } \\
(\mathrm{yr})\end{array}$ & $\begin{array}{l}\text { Women } \\
(\mathrm{n})\end{array}$ & $\begin{array}{l}\text { Platelet } \\
\left(x 10^{9} \text { cells/L) }\right. \\
\text { Mean }(95 \% \mathrm{CI})\end{array}$ & $\begin{array}{l}\text { MPV(fl) } \\
\text { Mean }(95 \% \mathrm{CI})\end{array}$ & $\begin{array}{l}\text { WBC count } \\
\left(x 10^{9} \text { cells/L) }\right. \\
\text { Mean(95\%CI) }\end{array}$ & $\begin{array}{l}\text { Neutrophil (\%) } \\
\text { Mean(95\% CI) }\end{array}$ & $\begin{array}{l}\text { Mixed }(\%) \\
\text { Mean(95\% CI) }\end{array}$ & $\begin{array}{c}\text { Lymphocyte (\%) } \\
\text { Mean (95\% CI) }\end{array}$ \\
\hline$<21 \mathrm{yr}$ & 41 & $233(215-251)$ & $11(10.3-11.3)$ & $8.3(7.6-8.9)$ & $68(65.5-70.6)$ & $8.3(7.3-9.1)$ & $23.6(21-25.9)$ \\
$21-25$ & 115 & $234(220-248)$ & $10.1(9.9-10.3)$ & $8.4(7.9-8.9)$ & $68(66.4-69.6)$ & $8.6(7.6-9.6)$ & $23.2(22-24.4)$ \\
$26-30$ & 162 & $224(214-248)$ & $10.3(10-10.4)$ & $8.3(8.0-8.7)$ & $68(66.9-69.5)$ & $8.7(7.8-9.6)$ & $23.4(22-24.6)$ \\
$31-35$ & 61 & $231(214-248)$ & $10.1(9.8-10.4)$ & $8.2(7.6-8.7)$ & $67.2(65-69.4)$ & $9.3(8.1-10.5)$ & $24(22.3-25.9)$ \\
$>36$ & 21 & $212(192-232)$ & $10.3(9.9-10.7)$ & $8.1(7-9.3)$ & $65.8(62.4-69)$ & $10.3(7-13.4)$ & $25(22-28.3)$ \\
Total & 400 & $228(221.6-235)$ & $10.3(10-10.4)$ & $8.3(8.1-8.6)$ & $67.9(67-68.7)$ & $8.8(8.3-9.3)$ & $23.6(23-24.3)$ \\
\hline
\end{tabular}

$W B C s=$ White Blood Cells, MPV=Mean Platelet Volume

DOI: http://dx.doi.org/10.4314/ejhs.v27i6.9 
Table 4: Distribution mean value with $95 \% \mathrm{CI} \mathrm{CD} 3^{+}, \mathrm{CD}^{+}, \mathrm{CD}^{+}$, and $\mathrm{CD} 4$ to $\mathrm{CD} 8$ ratio count, among HIV Sero-negative Pregnant Women by age groups at St. Paul's Hospital Millennium Medical College (SPHMMC), Addis Ababa, Ethiopia, From 01/03/2016 - 30/03/2016.

\begin{tabular}{cccllll}
\hline $\begin{array}{l}\text { Age } \\
\text { groups }\end{array}$ & $\begin{array}{l}\text { Number } \\
\text { Women }\end{array}$ & $\begin{array}{l}\mathrm{CD}^{+}(\mathrm{cells} / \mu \mathrm{l}) \\
\text { Mean }(95 \% \mathrm{CI})\end{array}$ & $\begin{array}{l}\mathrm{CD}^{+}(\mathrm{cells} / \mu \mathrm{l}) \\
\text { Mean }(95 \% \mathrm{CI})\end{array}$ & $\begin{array}{l}\mathrm{CD}^{+}(\mathrm{cell} / \mu \mathrm{l}) \\
\text { Mean }(95 \% \mathrm{CI})\end{array}$ & $\begin{array}{l}\text { CD4:CD8 Ratio } \\
\text { Mean (95\% CI) }\end{array}$ \\
\hline$<21$ & 41 & $1550(1383.9-1716.4)$ & $815(738-893)$ & $662(561-763)$ & $1.3(1.1-1.4)$ \\
$21-25$ & 115 & $1498(1389-1607)$ & $815(754-877)$ & $606(554-657)$ & $1.5(1.4-1.6)$ \\
$26-30$ & 162 & $1746(1622-1871)$ & $968(903-1033)$ & $727(667-787)$ & $1.5(1.4-1.6)$ \\
$31-35$ & 61 & $1808(1552-2063)$ & $994(857-1130)$ & $794(672-916)$ & $1.7(1.2-2.2)$ \\
$>36$ & 21 & $1899(1178-2619)$ & $859(706-1012)$ & $788(579-997)$ & $1.3(1.1-1.5)$ \\
Total & 400 & $1672(1591-1753)$ & $906(867-946)$ & $698(662-736)$ & $1.5(1.4-1.6)$ \\
\hline
\end{tabular}

Table 5: Distribution of Mean value with 95\%CI of Red blood cells, Hemoglobin and Hematocrit, among HIV Sero-negative Pregnant Women by age groups at St. Paul's Hospital Millennium Medical College (SPHMMC), Addis Ababa, Ethiopia, From 01/03/2016 - 30/03/2016.

\begin{tabular}{lllll}
\hline Age groups & $\begin{array}{l}\text { Number of } \\
\text { Women }\end{array}$ & $\begin{array}{l}\text { RBC }\left(\mathrm{X} 10^{2} \text { cells/L) }\right. \\
\text { Mean }(95 \% \mathrm{CI})\end{array}$ & $\begin{array}{l}\text { Hgb }(\mathrm{gm} / \mathrm{dl}) \\
\text { Mean }(95 \% \mathrm{CI})\end{array}$ & $\begin{array}{l}\text { Hct }(\%) \\
\text { Mean }(95 \% \mathrm{CI})\end{array}$ \\
\hline$<21$ & 41 & $4.5(4.3-4.7)$ & $13.5(13-14)$ & $39(38-40.5)$ \\
$21-25$ & 115 & $4.5(4.4-4.6)$ & $13.7(13.4-14)$ & $39.7(39-40)$ \\
$26-30$ & 162 & $4.4(4.4-4.5)$ & $14.5(12.7-16)$ & $39(38.8-39.8)$ \\
$31-35$ & 61 & $4.5(4.4-4.7)$ & $13.7(13.3-14)$ & $39.6(38.4-40.8)$ \\
$>36$ & 21 & $4.5(4.3-4.7)$ & $13.9(13.3-14.4)$ & $39.5(37.9-41)$ \\
Total & $\mathrm{N}=400$ & $4.5(4.4-4.5)$ & $14(13.3-14.7)$ & $39.5(39-39.9)$ \\
\hline
\end{tabular}

RBC $=$ Red Blood Cell, Hgb= hemoglobin, Hct= Hematocrite, $C I=$ Confidence Interval

Table 6: Distribution mean value with 95\% CI of RBC indices, among HIV Sero-negative Pregnant Women by age groups at St. Paul's Hospital Millennium Medical College (SPHMMC), Addis Ababa, Ethiopia, From 01/03/2016 - 30/03/2016.

\begin{tabular}{llllll}
\hline $\begin{array}{l}\text { Age } \\
\text { groups }\end{array}$ & $\begin{array}{l}\text { Number of } \\
\text { Women }\end{array}$ & $\begin{array}{l}\text { MCV }(\mathrm{fl}) \\
\text { Mean }(95 \% \mathrm{CI})\end{array}$ & $\begin{array}{l}\text { MCH }(\mathrm{pg} / \mathrm{dl}) \\
\text { Mean }(95 \% \mathrm{CI})\end{array}$ & $\begin{array}{l}\text { MCHC }(\mathrm{g} / \mathrm{dl}) \\
\text { Mean }(95 \% \mathrm{CI})\end{array}$ & $\begin{array}{l}\text { RDW } \\
\text { Mean }(95 \% \mathrm{CI})\end{array}$ \\
\hline$<21$ & 41 & $87(85-89)$ & $30(29-30.6)$ & $34.4(34-34.8)$ & $14(13.7-14.7)$ \\
$21-25$ & 115 & $87.4(86.4-88.5)$ & $30(29.8-30.7)$ & $34.6(34-34.9)$ & $14.3(14-14.6)$ \\
$26-30$ & 162 & $88.6(87.7-89.5)$ & $30.7(30.4-31)$ & $34.7(34.5-34.9)$ & $14(14-14.3)$ \\
$31-35$ & 61 & $87.6(86-89)$ & $30.5(30-31)$ & $34.8(34-35)$ & $14(13.6-14.7)$ \\
$>36$ & 21 & $88.8(86.6-91)$ & $31(30-32)$ & $35(34.5-35.4)$ & $13.8(13.5-14)$ \\
Total & 400 & $88(87.4-88.5)$ & $30.5(30.3-30.7)$ & $34.6(34.5-34.8)$ & $14.1(14-14.3)$ \\
\hline
\end{tabular}

$M C V=$ Mean Corpuscular Volume, MCH= Mean Corpuscular Hemoglobin, MCHC= Mean Corpuscular Hemoglobin Concentration, $R D W=$ Red Cell Width

\section{DISCUSSION}

To the best of the authors' knowledge, studies all over the world showed variability of immunohematological reference values particularly during pregnancy. Thus, reference values for pregnancy are mandatory rather than applying results derived from healthy adults. However, no specific studies have been conducted on pregnant women in Ethiopia.

We found slight increments of White blood cell counts (WBCs) and percent of mixed cells.

DOI: http://dx.doi.org/10.4314/ejhs.v27i6.9 
However, decline in absolute count of platelet and percent of Neutrophil concentration from the first to the third trimester observed. This rise of leukocytes during early pregnancy is well documented in the previous study (14).The increase observed in WBC count from the first to third trimester in this study is consistent with other findings $(14,15)$, which reported exactly the same pattern. This condition may be due to a response for physiological pregnancy pain and anxiety without infection. A gradual reduction in PLT count as pregnancy advanced, which is also consistent with the study done on Lagos, Nigeria(15), may be due to hemodilution.

Compared with other reference values established in Europe trimesters (WBC= $8108 \pm 1853, \quad 9086 \pm 1922, \quad 9516 \pm 1853$, Gran $=73.5 \pm 4.9,77.7 \pm 4.2,79.9 \pm 5.1)(14)$ and the United States $(\mathrm{WBC}=9.5 \pm 3,10.5 \pm 2.5,10.8 \pm 3.2$ ) (16), which we used as a reference, low values of WBC and granulocytes mean \pm SD $(95 \% \mathrm{CI})$ were found in each trimesters. The possible reason for these low values of variables may be genetic, nutritional or environmental variability.

The RBC parameters of Ethiopia are consistently higher than those of many other African countries; overall mean \pm SD of this study of $\mathrm{Hgb}$ was $14 \pm 7.2$, and for each trimester, values were $14.3 \pm 1.7,14.3 \pm 1.1,13.8 \pm 1.5$ higher compared to the previous study of overall mean $\pm \mathrm{SD}$ of Hgband each trimester values conducted in Lagos, Nigeria (15). Concerning Hct values, also the overall mean $\pm \mathrm{SD} ; 39.5 \pm 4.0$, and for each trimesters; $41.4 \pm 4.7,39 \pm 3.9,40 \pm 4$. These values were higher than the overall mean and each trimester studies done in Nigeria $(15,17)$. Again, the possible explanation for these higher values of RBC parameters may be high altitude and induction of erythropoiesis due to such altitudes.

The absolute count of Red Blood Cells (RBCs) and the concentration of Hemoglobin $(\mathrm{Hgb})$ gradually decrease from first to third trimester but a drop decrease in the percentage concentration of hematocrite in the second trimester observed. The progressive decline of the absolute count of RBC and Hgb concentration from the first to third trimester may be due to an increased demand for iron as pregnancy progresses. More iron is required to meet the expansion of maternal $\mathrm{Hb}$ mass and the needs of fetal growth, or it might be because of hormonal changes and fluid retention.

The overall mean \pm SD $(95 \% \quad \mathrm{CI})$ of RBCs seems higher than the previous report of Ethiopian reference values counts (11). This may happen because of the occurrence of erythropoiesis during pregnancy. However, the current study of $\mathrm{Hgb}$ and Hct is lower than the one from this earlier report of $\mathrm{Hgb}$ and Hct respectively (11). This may be due to the results of physiological factor since the participants of the current study were pregnant. During pregnancy expansion of the plasma volume may lower Hgb and Hct value or may be a reflection of adequate iron demand.

As compared to another study done in Ethiopia, RBC, Hgb and Hct (18), the values reported in the current study were higher. This may be because of the geographical location. Our study participants found at high altitude, and high altitude induced erythropoiesis for such variations. The red cell indices mean \pm SD and 95\% reference values, MCV appears to increase from the first to the third trimester while the $\mathrm{MCH}$ and $\mathrm{MCHC}$ relatively show constant concentrations; this values are slightly increased from the study done in Nigeria (15).

Regarding lymphocytes counts, relatively low percent of lymphocyte concentration was seemed to appeare in the second trimester whereas the absolute count of $\mathrm{CD}^{+}$cells and $\mathrm{CD}^{+} \mathrm{T}$ cells increase from the first to third trimesters. This relative reduction of lymphocyte indicates hemodilution as far as the absolute counts are not decreased.

The present study values for CD4+, CD8+ and the ratio of $\mathrm{CD} 4+$ to $\mathrm{CD} 8+\mathrm{T}$ cells mean $\pm \mathrm{SD}$ (95\% reference range) were higher than as compared to the earlier reports adult reference values from Ethiopia (11). This lymphocytosis difference may be due to the difference in the study participants since lymphocytosis increase during pregnancy. As compared to other studies, the overall absolute count of mean $\pm \mathrm{SD}$ for $\mathrm{CD} 4^{+}$ 
T-cells in this study $(906 \pm 404)$ value is higher than $\left(770\right.$ cells $/ \mathrm{mm}^{3} \pm 232$ cells $/ \mathrm{mm}^{3}$ ) the study done in Dar es Salaam, Tanzania(19). Also the second and the third trimesters $(885 \pm 370,940 \pm 444)$ seem to be appear higher than the study in USA $(810 \pm 181,800 \pm 179)$, respectively(16).The current study of overall mean $\pm \mathrm{SD}$ for absolute CD4 T-cell counts and CD8+Tcells $(940 \pm 444$ and $750 \pm 430)$ were higher than the study conducted in India (764 249 and $547 \pm$ 196), respectively (20).The possible explanation may be environmental factor, i.e., in more prevalent parasitic infection, the probability of getting high absolute count for those lymphocyte will increase.

In conclusion, reference values for HIVnegative pregnant women are rare in the literature. In this study, we reported reference values of mean \pm SD with $95 \%$ CI of immunohematological counts of pregnant women in SPHMMC, Addis Ababa, Ethiopia. These values were lower than the from developed countries but not lower than the from other African studies. Except for absolute and percentage count for immunohematological values in the health institution, we found no evidence about the general population and regarding the function of immune cells too. We suggest further large scale investigations which focus on the course of individual pregnancy and cellular activity.

\section{REFERENCES}

1. Zeh CE, Odhiambo CO, Mills LA. Laboratory Reference Intervals in Africa. 2012: http://cdn.intechopen.com/pdfs/39110/

2. Nebeck K, Gelaye B, Lemma S, Berhane Y, Bekele T, Khali A, et al. Hematological parameters and metabolic syndrome: Findings from an occupational cohort in Ethiopia. Diabetes Metab Syndr Clin Res Rev. 2012 Jan 1;6(1):22-7.

3. Chandra S, Tripathi AK, Mishra S, Amzarul M, Vaish AK. Physiological changes in hematological parameters during pregnancy. Indian J Hemato/Blood Transfus. 2012 Sep;28(3):144-6.

4. Buchanan AM, Muro FJ, Gratz J, Crump JA, Musyoka AM, Sichangi MW, et al.
Establishment of haematological and immunological reference values for healthy Tanzanian children in Kilimanjaro Region. Trop Med Int Health TM IH. 2010 Sep;15(9):1011-21.

5. Smith GFD. An Investigation into Some of the Effects of the State of Nutrition of the Mother During Pregnancy and Labour on the Condition of the Child at Birth and for First Few Days of Life. The Lancet. 1916 Jul;188(4845):54-6.

6. James TR, Reid HL, Mullings AM. Are published standards for haematological indices in pregnancy applicable across populations: an evaluation in healthy pregnant Jamaican women. BMC Pregnancy Childbirth. 2008 Feb 28;8(1):8.

7. Elgari MM. Evaluation of Hematological Parameters of Sudanese Pregnant Women attending at Omdurman Al Saudi Maternity Hospital.http://physiology.eajbs.eg.net/pdf

8. Ichipi-Ifukor PC, Jacobs J, Ichipi-Ifukor RN, Ewrhe OL. Changes in Haematological Indices in Normal Pregnancy. Physiol J. 2013 Dec 30;2013:e283814.

9. Centers for Disease Control and Prevention (CDC). Use of dietary supplements containing folic acid among women of childbearing age-United States, 2005. MMWR Morb Mortal Wkly Rep. 2005 Sep 30;54(38):955-8.

10. Garn SM, Keating MT, Falkner F. Hematological status and pregnancy outcomes. Am J Clin Nutr. 1981 Jan 1;34(1):115-7.

11. Tsegaye A, Messele T, Tilahun T, Hailu E, Sahlu T, Doorly R, et al. Immunohematological Reference Ranges for Adult Ethiopians. Clin Diagn Lab Immunol. 1999 May 1;6(3):410-4.

12. Abdulkadir J, Bolodia G. Haemoglobin and haematocrit levels in young adult Ethiopian males in Addis Ababa. Ethiop Med J. 1979 Jan; 17(1):5-8.

13. Peters WH. Haematocrit and haemoglobin levels in adult males and in pregnant and nonpregnant females in Northern Ethiopia. Ethiop Med J. 1984;22(1):17-27. 
14. Kühnert M, Strohmeier R, Stegmüller M, Halberstadt E. Changes in lymphocyte subsets during normal pregnancy. Eur $J$ Obstet Gynecol Reprod Biol. 1998 Feb 1;76(2):14751.

15. Akinbami AA, Ajibola SO, Rabiu KA, Adewunmi AA, Dosunmu AO, Adediran A, et al. Hematological profile of normal pregnant women in Lagos, Nigeria. Int $J$ Womens Health. 2013 May 3;5:227-32.

16. Towers CV, Rumney PJ, Ghamsary MG. Longitudinal study of CD4+ cell counts in HIV-negative pregnant patients. J Matern Fetal Neonatal Med. 2010 Oct 1;23(10):10916.

17. Akingbola TS, Adewole IF, Adesina OA, Afolabi KA, Fehintola FA, Bamgboye EA, et al. Haematological profile of healthy pregnant women in Ibadan, South-western Nigeria. $J$ Obstet Gynaecol. 2006 Jan 1;26(8):763-9.

18. Haileamlak A, Muluneh AT, Alemseged F, Tessema F, Woldemichael K, Asefa M, et al. Hematoimmunological profile at gilgel gibe field research center, southwest ethiopia. Ethiop J Health Sci. 2012 Aug;22(5):39-50.

19. Kapiga SH, Mwakagile D, Spiegelman D, Msamanga GI, Hunter D, Fawzi WW. Predictors of CD4+ lymphocyte count among HIV-seropositive and HIV-seronegative pregnant women in Dar es Salaam, Tanzania. East Afr $\quad$ Med $J$. http://www.ajol.info/index.php/eamj/.

20. Dayama A, Pandit D, Mudaliar S, Bharadwaj $\mathrm{R}$, others. A pilot study on CD4 \& CD8 cell counts in healthy HIV seronegative pregnant women. Indian J Med Res. 2003;117:198. 